\title{
OPTIMIZATION ON TURNING PARAMETERS OF 15-5PH STAINLESS STEEL USING TAGUCHI BASED GREY APPROACH AND TOPSIS
}

\begin{abstract}
The machinability and the process parameter optimization of turning operation for 15-5 Precipitation Hardening $(\mathrm{PH})$ stainless steel have been investigated based on the Taguchi based grey approach and Technique for Order Preference by Similarity to Ideal Solution (TOPSIS). An $L_{27}$ orthogonal array was selected for planning the experiment. Cutting speed, depth of cut and feed rate were considered as input process parameters. Cutting force $\left(F_{z}\right)$ and surface roughness $\left(R_{a}\right)$ were considered as the performance measures. These performance measures were optimized for the improvement of machinability quality of product. A comparison is made between the multi-criteria decision making tools. Grey Relational Analysis (GRA) and TOPSIS are used to confirm and prove the similarity. To determine the influence of process parameters, Analysis of Variance (ANOVA) is employed. The end results of experimental investigation proved that the machining performance can be enhanced effectively with the assistance of the proposed approaches.
\end{abstract}

\section{Introduction}

The demand for using special type of stainless steel is increasing in many of the engineering applications. 15-5PH stainless steel is extensively used in aerospace parts, valves, gears and fasteners to withstand high pressure and corrosive environment. Machining can be done on 15-5PH stainless steel alloy at any obtainable condition due to its ductile property. Compared with the other PH steels, 15-5 PH provides dimensional stability and better polishing ability [1, 2]. Paulo Davim et al. [3] reported the importance of predicting surface integrity of 15-5 PH stainless steel which makes more attention in nuclear and aerospace applications. Kumar et al. [4] reported that 15-5 PH is more predominant than 17-4 PH stainless steel. In the solution treated condition this

\footnotetext{
${ }^{1}$ Production Department, National Institute of Technology, Tiruchirappalli, India-620015; Emails:dpalanisamy.me@gmail.com,senthil@nitt.edu
} 
material can be machined at the rate similar to SS 304. Aldo Braghini Junior et al. [5] demonstrated that during machining 15-5 PH stainless steel, lubricating and cooling condition mostly affect the mechanism of tool wear and the life of tool. It was concluded that the importance should be given to tool lubrication than tool cooling to overcome tool damage due to temperature variations and the selection of cutting fluid has also influenced on tool damage.

Plasma nitro carburizing was performed on the precipitated hardenable stainless steel to increase the mechanical properties and found that the treated specimen is having surface hardness three times higher than the untreated material [6, 7]. Zhou Wang et al. [8] proved that the fatigue life of PH stainless steel increased dramatically after laser hardening treatment and with the influence of shot peening there is an increase in depth of the residual stress. Zhaoyun et al. [9] investigated the hardness and microstructure of laser quenched PH stainless steel and proved that hardened zone has higher hardness than the substrate, and the depth of hardness varies from surface up to $1.75 \mathrm{~mm}$. The relationship between mechanical properties and high temperature heat treatment of 15-5 PH stainless steel was investigated. It was stated that the value of fracture toughness gets reduced whereas the yield strength remained unaltered after solution heat treatment $[10,11]$.

Fnides et al. [12] concluded that cutting forces are the salient parameter to evaluate the essential power required for machining and are also considered while dimensioning and designing the machine components. Cutting forces have significant influences on deformation, dimensional accuracy, machining system and chip formation of machined workpiece. Noordin et al. [13] observed that longer tool life and better surface finish were achieved at higher nose radius, low depth of cut and low feed rate while turning hardened stainless steel. Axinte et al. [14] described that the most significant factor which affects the quality of machined part is surface roughness. The poor surface quality during machining of difficult to machine material is due to variation in cutting temperature produced, higher cutting speed and higher feed rate. The higher temperature produced during machining is the main cause for dimensional deviation and cutting tool failure.

Prasanna et al. [15] evaluated the process performance of hole drilling through overcut, thrust force, taper and circularity. Mathematical modelling and multi-performance characteristics optimization of machining parameters were done using GRA. The results revealed that thrust force is controlled by cutting velocity and feed. The most significant parameters that affects dimensional accuracy of hole are cutting speed and pressure of air. Experimental work using ball nose in an end mill cutter in micro-milling of aluminium was carried out with four different stages such as modelling, experimental work, single and multi-objective optimization. The process parameters and their effects on 
responses were optimized by GRA and ANOVA [16]. Tzeng et al. [17] used grey relational approach technique to find the optimal machining parameters in CNC turning and identified that the most influencing parameter that affects roughness average is the depth of cut. The roughness and roundness is mostly influenced by cutting velocity. The most significant factor was calculated using ANOVA and found that the depth of cut influences more than other parameters. Turning experiments on AISI 6061 T6 were performed in rough condition to optimize the machining process parameters. It was concluded that machining at higher feed rate reduced the energy consumption but increased the surface roughness [18].

Y. Tansel İç [19] used Design of Experiment (DOE) and TOPSIS method for identifying the critical selection and interaction of attributes using multiple linear regression analysis by fitting appropriate polynomial in the experimental data. Gadakh [20] used TOPSIS method to solve multiple criteria optimization problem and stated that it is an effective tool for complicated decision making. Y. Tansel İç [21] used both Design of Experiment and TOPSIS methods together to rank the companies and with the help of developed model, satisfactory results were obtained in the real-time financial environment. Vinodh et al. [22] developed an assessment model, based on Analytic Hierarchy Process (AHP) and TOPSIS, in a fuzzy environment to carry out performance evaluation to identify the best method for recycling plastics among the various plastic recycling processes.

This present study investigates the impact of different process parameters, particularly on cutting force $\left(F_{z}\right)$ and surface roughness $\left(R_{a}\right)$ in CNC turning of 15-5 PH steel in the as received condition. Experiments are planned based on Taguchi design method. The outcomes are investigated to attain optimal cutting force $\left(F_{z}\right)$ and surface roughness $\left(R_{a}\right)$. A comparison is made between the multi criteria decision making tools of Grey Relational Analysis (GRA) and TOPSIS to ensure the similarity between them. The most influencing parameters which affect the outputs were investigated by performing ANOVA using statistical software Minitab 16.

\section{Experimental details}

\subsection{Materials and processes}

Turning experiments were conducted on a LEADWELL CNC turning machine with a $7.5 \mathrm{~kW}$ motor, feed range up to $24000 \mathrm{~mm} / \mathrm{min}$, and a maximum spindle speed of $4500 \mathrm{rpm}$ at dry condition. The material used for the experiments was 15-5 PH stainless steel of $30 \mathrm{~mm}$ diameter and $120 \mathrm{~mm}$ length. Table 1 gives the detailed information of chemical composition in 15-5 PH 
stainless steel. A tool holder with a general specification PCLNL 1616 H12 was used in this experiment. Tungsten carbide inserts of CNMG 120408-GM coated with TiAlN were used as the cutting tool insert. Cutting forces $\left(F_{z}\right)$ were measured using three component KISTLER 9257 B type dynamometer. Average surface roughness $\left(R_{a}\right)$ values were measured using Mitutoyo SJ301 surface roughness tester. Surface roughness was measured along the longitudinal direction of the machined surface at four different locations and the average values are evaluated for the responses. To avoid uncertainty during dismantling and assembly of the workpiece, surface roughness measurements were directly measured without removing the turned part from the $\mathrm{CNC}$ machine.

Table 1.

Chemical composition of as received 15-5 PH stainless steel

\begin{tabular}{|c|c|c|c|c|c|c|c|c|c|}
\hline Constituents & $\mathrm{C}$ & $\mathrm{Mn}$ & $\mathrm{P}$ & $\mathrm{S}$ & $\mathrm{Si}$ & $\mathrm{Cr}$ & $\mathrm{Ni}$ & $\mathrm{Cu}$ & $\mathrm{Nb}$ with $\mathrm{Ta}$ \\
\hline Weight \% & 0.03 & 0.78 & 0.0290 & 0.010 & 0.270 & 15.17 & 3.97 & 3.12 & 0.270 \\
\hline
\end{tabular}

\subsection{Design of experiments}

Taguchi method is one of the powerful tools for improving the productivity at low cost. To study the whole parameter space with a small number of experiments, Taguchi method uses a special design of orthogonal arrays [2325]. The methodology of Taguchi for $3 \times 3$ levels, an $L_{27}$ orthogonal array was used to outline the trial conditions in the implementation of the plan of experiments. Table 2 shows the machining process parameters and their levels.

Table 2.

Machining process parameters and their levels

\begin{tabular}{|c|c|c|c|c|}
\hline Parameter & Unit & Level I & Level II & Level III \\
\hline Cutting speed $\left(V_{c}\right)$ & $\mathrm{m} / \mathrm{min}$ & 100 & 160 & 220 \\
\hline Feed rate $(f)$ & $\mathrm{mm} / \mathrm{rev}$ & 0.1 & 0.15 & 0.2 \\
\hline Depth of cut $\left(a_{p}\right)$ & $\mathrm{mm}$ & 0.3 & 0.6 & 0.9 \\
\hline
\end{tabular}

Each experiment of the $L_{27}$ trials was repeated twice and the average values of response were tabulated for the analysis. Table 3 shows the experimental plan and average test results for the corresponding experiments. From the literature survey, it has been observed that to analyse and find the best parameter of single performance characteristics Taguchi method can be applied. Whereas, in analysing test results of multi-performance characteristics, Grey Relational Analysis (GRA) and Technique for Order Preference by Similarity to Ideal Solution (TOPSIS) can be used effectively. 
Table 3.

Experimental layout and corresponding results of cutting force and surface roughness using $L_{27}$ orthogonal array

\begin{tabular}{|c|c|c|c|c|c|}
\hline $\begin{array}{l}\text { Exp. } \\
\text { No. }\end{array}$ & $\begin{array}{l}\text { Cutting speed } \\
\qquad\left(V_{c}\right)\end{array}$ & $\begin{array}{l}\text { Feed rate } \\
\qquad(f)\end{array}$ & $\begin{array}{l}\text { Doc } \\
\left(a_{p}\right)\end{array}$ & $\begin{array}{l}\text { Cutting force } \\
\qquad\left(F_{z}\right) \mathrm{N}\end{array}$ & $\begin{array}{l}\text { Surface roughness } \\
\left(R_{a}\right) \mu \mathrm{m}\end{array}$ \\
\hline 1 & 100 & 0.1 & 0.3 & 83.25 & 0.54 \\
\hline 2 & 100 & 0.1 & 0.6 & 222.64 & 0.65 \\
\hline 3 & 100 & 0.1 & 0.9 & 302.12 & 0.51 \\
\hline 4 & 100 & 0.15 & 0.3 & 130.24 & 1.13 \\
\hline 5 & 100 & 0.15 & 0.6 & 251.24 & 1.19 \\
\hline 6 & 100 & 0.15 & 0.9 & 390.75 & 1.22 \\
\hline 7 & 100 & 0.2 & 0.3 & 196.50 & 1.66 \\
\hline 8 & 100 & 0.2 & 0.6 & 315.50 & 1.88 \\
\hline 9 & 100 & 0.2 & 0.9 & 468.22 & 1.99 \\
\hline 10 & 160 & 0.1 & 0.3 & 104.13 & 0.53 \\
\hline 11 & 160 & 0.1 & 0.6 & 183.47 & 0.65 \\
\hline 12 & 160 & 0.1 & 0.9 & 279.38 & 0.87 \\
\hline 13 & 160 & 0.15 & 0.3 & 127.02 & 1.13 \\
\hline 14 & 160 & 0.15 & 0.6 & 236.97 & 1.08 \\
\hline 15 & 160 & 0.15 & 0.9 & 382.82 & 1.21 \\
\hline 16 & 160 & 0.2 & 0.3 & 180.76 & 1.58 \\
\hline 17 & 160 & 0.2 & 0.6 & 251.84 & 1.64 \\
\hline 18 & 160 & 0.2 & 0.9 & 431.36 & 1.87 \\
\hline 19 & 220 & 0.1 & 0.3 & 95.37 & 0.30 \\
\hline 20 & 220 & 0.1 & 0.6 & 160.00 & 0.59 \\
\hline 21 & 220 & 0.1 & 0.9 & 260.09 & 0.51 \\
\hline 22 & 220 & 0.15 & 0.3 & 105.12 & 0.73 \\
\hline 23 & 220 & 0.15 & 0.6 & 207.13 & 0.74 \\
\hline 24 & 220 & 0.15 & 0.9 & 351.11 & 0.88 \\
\hline 25 & 220 & 0.2 & 0.3 & 172.73 & 1.33 \\
\hline 26 & 220 & 0.2 & 0.6 & 263.68 & 1.41 \\
\hline 27 & 220 & 0.2 & 0.9 & 405.62 & 1.63 \\
\hline
\end{tabular}

\section{Optimization}

\subsection{Grey Relational Analysis}

Experimental results are integrated with a Grey Relational Approach to investigate the three machining parameters (cutting speed, feed rate and depth of cut) at three levels with respect to surface roughness and cutting force.

The steps involved in GRA are as follows. 
Step 1: According to the experimental plan all the experimental results are obtained and tabulated.

Step 2: Usually data normalization is of three types, namely Nominal the Best (NB), Higher the Better (HB) and Lower the Better (LB) $[24,25]$. In this experimental study, lower the better criteria have been chosen for cutting force and surface roughness. Hence equation (1) is used for normalization of the original sequence of this response.

$$
y_{i}^{*}(k)=\frac{\max y_{i}(k)-y_{i}(k)}{\max y_{i}(k)-\min y_{i}(k)} \quad \ldots
$$

where $\mathrm{y}_{i}^{*}(k)$ is the normalized data, i.e. after grey relational generation, $\max \mathrm{y}_{i}(k)$ is the highest value and $\min \mathrm{y}_{i}(k)$ is the lowest value of $\mathrm{y}_{i}(k)$ for the $k$ th response and $\mathrm{y}_{i}(k)$ is the $k$ th response of the $i$ th experiment. Step 3: Grey Relational Coefficient (GRC) is calculated using the following equation.

$$
\varepsilon_{i}(k)=\frac{\Delta \min +\omega \Delta \max }{\Delta_{o i}(k)+\omega \Delta \max } \quad \cdots
$$

where $\varepsilon_{i}(k)$ is the Grey Relation Coefficient (GRC), $\Delta$ max is the highest value of $\Delta_{o i}(k), \Delta \min$ is the lowest value of $\Delta_{o i}(k), \Delta_{o i}(k)=\left\|y_{o}^{*}(k)-y_{i}^{*}(k)\right\|$ i.e., absolute of the difference between $y_{o}^{*}(k)$ and $y_{i}^{*}(k) . y_{o}^{*}(k)$ is the ideal or reference sequence.

Step 4: The grey relational grade $\left(\Gamma_{i}\right)$ is found using the following relation

$$
\Gamma_{i}=\frac{1}{n} \sum_{i=1}^{Q} \varepsilon_{i}(k) \quad \ldots
$$

where $Q$ is the total number of responses and $n$ is the number of output responses. The parameter which has the highest value of grey relational grade is the optimal machining condition for the selected set of experiments.

\subsection{TOPSIS}

TOPSIS method is used for the selection of the best alternative from the available alternatives and the steps involved are as follows.

Step 1: The twenty seven alternatives are evaluated. In this specific problem, the attributes are cutting force and surface roughness which are considered as non-beneficial (lower values).

Step 2: All the information available is presented in the form of a decision matrix. Table 3 shows the D $27 \times 3$ matrix. 
Step 3: Equation (4) is used to normalize the output values of the turning process, Table 9 shows the normalized matrix of R $27 \times 3$.

$$
R_{i j}=x_{i j} / \sqrt{\sum x_{i j}^{2}} \text { for } i=1, \ldots, m, j=1, \ldots, n .
$$

Step 4: According to the relative importance of attributes, weights are considered. All attributes are considered as equal, the associated weights are $F_{z}=0.5$; $R_{a}=0.5$ and the sum of weight is one. Using equation (5) weighted normalized decision matrix is constructed.

$$
V_{i j}=w_{j} R_{i j} \quad \ldots
$$

where: $j=1,2 \ldots n, i=1,2 \ldots m$; here $w_{j}$ is the weight of the $j$ th attribute. Step 5: Equations (6) and (7) are used to determine the positive ideal solution (PIS) $A^{*}$ and negative ideal solution (NIS) $A^{\prime}$.

$$
\begin{aligned}
& \qquad A^{*}=\left\{V_{1}^{*}, \ldots, V_{n}^{*}\right\}, \\
& \text { where } V_{i}^{*}=\left\{\max \left(V_{i j}\right) \text { if } j \in J ; \min \left(V_{i j}\right) \text { if } j \in J^{\prime}\right\}, \\
& \qquad A^{\prime}=\left\{V_{1}^{\prime}, \ldots, V_{n}^{\prime}\right\}, \\
& \text { where } V_{i}^{\prime}=\left\{\min \left(V_{i j}\right) \text { if } j \in J ; \max \left(V_{i j}\right) \text { if } j \in J^{\prime}\right\},
\end{aligned}
$$

where $J^{\prime}$ is a set of cost attributes and $J$ is a set of beneficial attributes.

Step 6: Equations (8) and (9) are used to find the separation measures, from the positive ideal and negative ideal solution.

$$
\begin{aligned}
& S_{i}^{*}=\left[\sum\left(V_{j}^{*}-V_{i j}\right)^{2}\right]^{1 / 2} \quad i=1, \ldots, m \\
& S_{i}^{\prime}=\left[\sum\left(V_{j}^{\prime}-V_{i j}\right)^{2}\right]^{1 / 2} \quad i=1, \ldots, m .
\end{aligned}
$$

Step 7: Equation (10) is used to calculate relative closeness to the ideal solution.

$$
C_{i}^{*}=S_{i}^{\prime} /\left(S_{i}^{*}+S_{i}^{\prime}\right) \quad 0 \leqslant C_{i}^{*} \leqslant 1
$$

Step 8: The alternatives are ranked based on the closeness index in descending order. The alternative having greater $C_{i}^{*}$ value shows the improved performance. 


\subsection{Analysis of variance}

Statistical method ANOVA is used to find the effect and impact of every individual parameter on results. The effect of individual parameters cannot be assessed using Taguchi method, while ANOVA well determines the percentage contribution of individual parameters. Statistical software Minitab16 was used to model and investigate the effect of machining parameters (cutting speed, feed rate and depth of cut) on individual responses and multiple responses.

\section{Results and discussion}

\subsection{Effect of process parameters on cutting force}

The influence of process parameters on cutting force is shown in Fig. 1. The cutting force declines with increasing cutting speed.

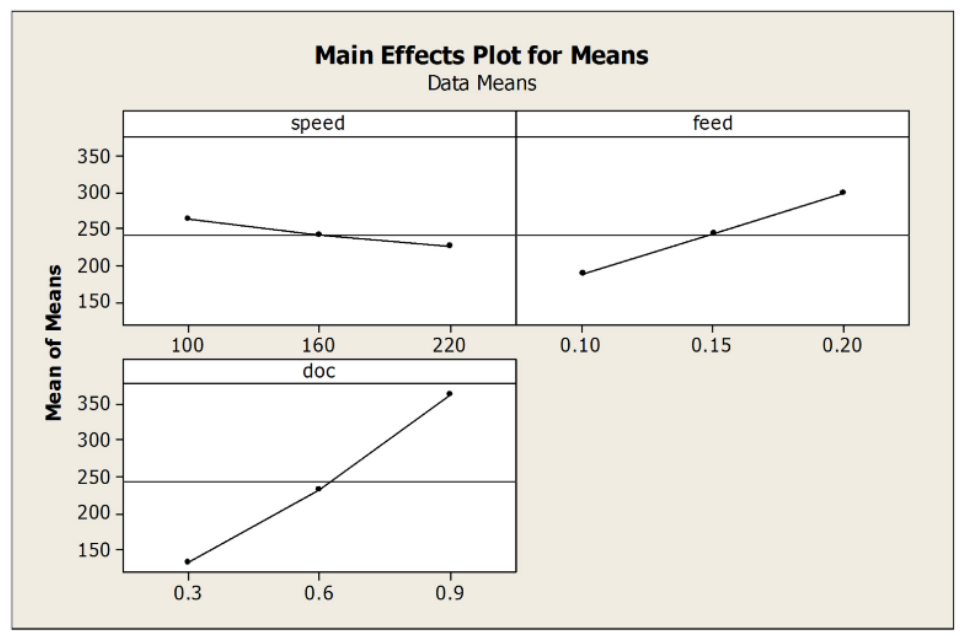

Fig. 1. Effects plots for cutting force

Whereas at lower cutting speed, the cutting force required is higher due to the effect of the coefficient of friction between the tool and workpiece. While machining at higher speed, the temperature generated is greater at the cutting zone or the tool-work interface which makes the workpiece softer and hence the material removal is possible at lower cutting force. Whilst the increase in feed rate, the cutting force increases due to the more contact length of tool insert and work material at all speeds. Similarly, increase in depth of cut increases the cutting force. Moreover, the material removal rate is high at deeper cuts which require higher cutting force. 
Table 4 shows the response for means of cutting force and it is found that the major factor affecting the cutting force is the depth of cut followed by the feed rate and the cutting speed.

Table 4.

Response table for means of cutting force

\begin{tabular}{|c|c|c|c|}
\hline Level & Cutting speed $\left(V_{c}\right)$ & Feed $(f)$ & Doc $\left(a_{p}\right)$ \\
\hline 1 & 262.3 & 187.8 & 132.8 \\
\hline 2 & 242 & 242.5 & 232.5 \\
\hline 3 & 224.5 & 298.5 & 363.5 \\
\hline Delta & 37.7 & 110.6 & 230.7 \\
\hline Rank & 3 & 2 & 1 \\
\hline
\end{tabular}

Table 5 illustrates the results of ANOVA for cutting force. It shows that the depth of cut is the most influencing parameter that affects the cutting force and the percentage of contribution is about $(77.34 \%)$ and it is trailed by feed rate $(17.68 \%)$ and the cutting speed $(2.06 \%)$ respectively.

Table 5 .

ANOVA for cutting force

\begin{tabular}{|c|c|c|c|c|c|c|}
\hline Source & DF & Seq SS & Adj SS & Adj MS & F & \% C \\
\hline Speed & 2 & 6420 & 6420 & 3210 & 32.61 & 2.06 \\
\hline Feed & 2 & 55088 & 55088 & 27544 & 279.86 & 17.68 \\
\hline DOC & 2 & 240982 & 240982 & 120491 & 1224.23 & 77.34 \\
\hline speed·feed & 4 & 853 & 853 & 213 & 2.17 & \\
\hline feed·doc & 4 & 5568 & 5568 & 1392 & 14.14 & \\
\hline speed·doc & 4 & 1879 & 1879 & 470 & 4.77 & \\
\hline Error & 8 & 787 & 787 & 98 & & \\
\hline Total & 26 & 311578 & & & & \\
\hline
\end{tabular}

\subsection{Effect of process parameters on surface roughness}

Fig. 2 illustrates the effect of process parameters on surface roughness. When the level of cutting speed increases from 100 to $220 \mathrm{~m} / \mathrm{min}$, the value of surface roughness reduces due to thermal softening of workpiece. The increase in feed and depth of cut causes friction due to increase in contact length between work material and tool edge interface. Hence, the value of surface roughness increases.

The response for means of surface roughness is shown in Table 6 and it is found that, for the selected set of parameters, the major factor which affect the surface roughness is in the order of feed rate followed by cutting speed and depth of cut. Table 7 shows the results of ANOVA for surface roughness. 


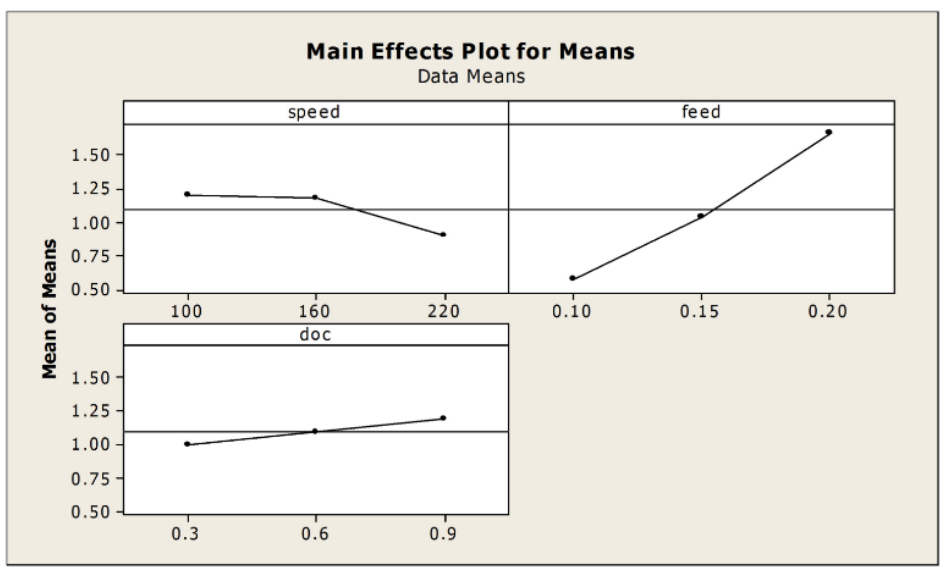

Fig. 2. Main effects plots for surface roughness

Table 6.

Response table for means of surface roughness

\begin{tabular}{|c|c|c|c|}
\hline Level & Cutting speed $\left(V_{c}\right)$ & Feed $(f)$ & Doc $\left(a_{p}\right)$ \\
\hline 1 & 1.1955 & 0.5716 & 0.9921 \\
\hline 2 & 1.1737 & 1.0344 & 1.0918 \\
\hline 3 & 0.9021 & 1.6654 & 1.1875 \\
\hline Delta & 0.2934 & 1.0938 & 0.1954 \\
\hline Rank & 2 & 1 & 3 \\
\hline
\end{tabular}

It implies that the most significant parameter affecting the surface roughness is the feed rate $(86.07 \%)$ and it is followed by cutting speed $(7.62 \%)$ and the depth of cut $(2.72 \%)$ respectively.

ANOVA for surface roughness

Table 7.

\begin{tabular}{|c|c|c|c|c|c|c|}
\hline Source & DF & Seq. SS & Adj. SS & Adj. MS & F & \% C \\
\hline Speed & 2 & 0.48103 & 0.48103 & 0.2405 & 48.43 & 7.62 \\
\hline Feed & 2 & 5.42629 & 5.42629 & 2.7131 & 546.34 & 86.07 \\
\hline DOC & 2 & 0.17192 & 0.17192 & 0.0859 & 17.31 & 2.72 \\
\hline speed·feed & 4 & 0.10307 & 0.10307 & 0.0257 & 5.19 & \\
\hline feed·doc & 4 & 0.05266 & 0.05266 & 0.0131 & 2.65 & \\
\hline speed·doc & 4 & 0.03 & 0.03 & 0.0075 & 1.51 & \\
\hline Error & 8 & 0.03973 & 0.03973 & 0.0049 & & \\
\hline Total & 26 & 6.3047 & & & & \\
\hline
\end{tabular}




\subsection{Multiple objective optimization using GRA and TOPSIS}

Table 8 shows the responses table for both cutting force and surface roughness. It is found that the optimal process parameter set is the 19th experiment having levels of $V_{c} 3 f l a_{p} l$ which means the cutting speed is $220 \mathrm{~m} / \mathrm{min}$, feed rate is $0.1 \mathrm{~mm} / \mathrm{rev}$ and depth of cut is $0.3 \mathrm{~mm}$. A similarity with Taguchi method is found from the response table of the grey relation grade which shows the

Response table for the grey relational grade

\begin{tabular}{|c|c|c|c|}
\hline $\begin{array}{c}\text { Process } \\
\text { parameter }\end{array}$ & $\begin{array}{c}\text { Cutting speed } \\
\left(V_{c}\right)\end{array}$ & $\begin{array}{c}\text { Feed } \\
(f)\end{array}$ & $\begin{array}{c}\text { Depth of cut } \\
\left(a_{p}\right)\end{array}$ \\
\hline Level 1 & 0.5561 & $0.7333^{*}$ & $0.7111^{*}$ \\
\hline Level 2 & 0.5609 & 0.5720 & 0.5635 \\
\hline Level 3 & $0.6334^{*}$ & 0.4451 & 0.4758 \\
\hline Max-Min & 0.0773 & 0.2882 & 0.2353 \\
\hline Rank & 3 & 1 & 2 \\
\hline * indicates the optimum levels. \\
\hline
\end{tabular}

feed rate is the most influencing factor, followed by the depth of cut and speed. Table 9 illustrates the grey relational grade for all trial using $L_{27}$ orthogonal array. If the grey relational grade is higher, the product quality will be better. Consequently, on the basis of grey relational grade, the effect of individual factor can be assessed and also the best level for each controllable factor can be identified.

Fig. 3 shows the grey relational grade graph for the levels of the processing parameters and it is found that the speed $(220 \mathrm{~m} / \mathrm{min})$ at third level, feed

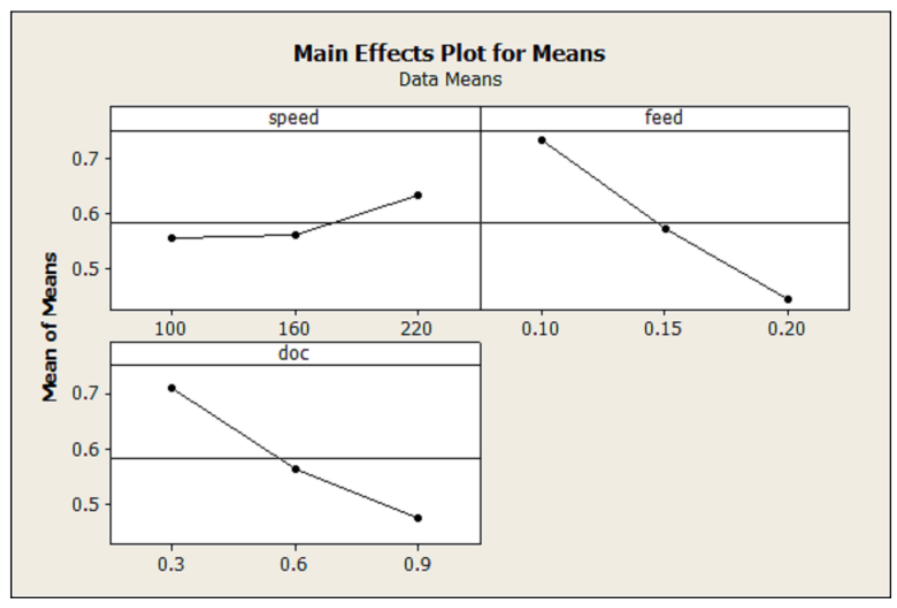

Fig. 3. Main effects plots for grey relation grade 
D. PALANISAMY, P. SENTHIL

Table 9.

Evaluated grey relational co-efficient and grade values

\begin{tabular}{|c|c|c|c|c|c|c|}
\hline \multirow{2}{*}{$\begin{array}{l}\text { Exp. } \\
\text { No. }\end{array}$} & \multicolumn{2}{|c|}{ Normalized Values } & \multicolumn{2}{|c|}{$\begin{array}{c}\text { Grey Relational Co-efficient } \\
\text { after Weighted }\end{array}$} & \multirow{2}{*}{$\begin{array}{l}\text { Grey relation } \\
\text { grade }\end{array}$} & \multirow{2}{*}{ Rank } \\
\hline & $\begin{array}{l}\text { Cutting } \\
\text { force } F_{z}\end{array}$ & $\begin{array}{l}\text { Surface } \\
\text { roughness }\end{array}$ & $\begin{array}{l}\text { Cutting } \\
\text { force }\end{array}$ & $\begin{array}{l}\text { Surface } \\
\text { roughness }\end{array}$ & & \\
\hline 1 & 1 & 0.8573 & 1 & 0.7779 & 0.8889 & 2 \\
\hline 2 & 0.6379 & 0.7940 & 0.5799 & 0.7082 & 0.6441 & 10 \\
\hline 3 & 0.4314 & 0.8764 & 0.4679 & 0.8018 & 0.6348 & 11 \\
\hline 4 & 0.8779 & 0.5084 & 0.8037 & 0.5042 & 0.6540 & 9 \\
\hline 5 & 0.5636 & 0.4730 & 0.5339 & 0.4868 & 0.5104 & 17 \\
\hline 6 & 0.2012 & 0.4552 & 0.3849 & 0.4785 & 0.4317 & 23 \\
\hline 7 & 0.7058 & 0.1974 & 0.6295 & 0.3838 & 0.5067 & 18 \\
\hline 8 & 0.3967 & 0.0656 & 0.4531 & 0.3485 & 0.4008 & 24 \\
\hline 9 & 0 & 0 & 0.3333 & 0.3333 & 0.3333 & 27 \\
\hline 10 & 0.9457 & 0.8628 & 0.9021 & 0.7847 & 0.8434 & 3 \\
\hline 11 & 0.7396 & 0.7922 & 0.6576 & 0.7064 & 0.6820 & 6 \\
\hline 12 & 0.4905 & 0.6621 & 0.4953 & 0.5968 & 0.5460 & 14 \\
\hline 13 & 0.8863 & 0.5084 & 0.8147 & 0.5042 & 0.6595 & 8 \\
\hline 14 & 0.6006 & 0.5380 & 0.5559 & 0.5197 & 0.5378 & 15 \\
\hline 15 & 0.2218 & 0.4611 & 0.3911 & 0.4813 & 0.4362 & 22 \\
\hline 16 & 0.7467 & 0.2406 & 0.6637 & 0.3970 & 0.5303 & 16 \\
\hline 17 & 0.5620 & 0.2069 & 0.5330 & 0.3866 & 0.4598 & 21 \\
\hline 18 & 0.0957 & 0.070 & 0.3560 & 0.3498 & 0.3529 & 26 \\
\hline 19 & 0.9685 & 1 & 0.9407 & 1 & 0.9703 & 1 \\
\hline 20 & 0.8006 & 0.8277 & 0.7149 & 0.7437 & 0.7293 & 5 \\
\hline 21 & 0.5406 & 0.8750 & 0.5211 & 0.8000 & 0.6606 & 7 \\
\hline 22 & 0.9431 & 0.7449 & 0.8979 & 0.6622 & 0.7801 & 4 \\
\hline 23 & 0.6782 & 0.7390 & 0.6084 & 0.6570 & 0.6327 & 12 \\
\hline 24 & 0.3042 & 0.6562 & 0.4181 & 0.5926 & 0.5053 & 19 \\
\hline 25 & 0.7675 & 0.3900 & 0.6826 & 0.4504 & 0.5665 & 13 \\
\hline 26 & 0.5313 & 0.3429 & 0.5161 & 0.4321 & 0.4741 & 20 \\
\hline 27 & 0.1626 & 0.2128 & 0.3738 & 0.3884 & 0.3811 & 25 \\
\hline
\end{tabular}

$(0.1 \mathrm{~mm} / \mathrm{rev})$ at first level and depth of cut $(0.3 \mathrm{~mm})$ at first level are the optimum parameters of multi performance characteristics.

Table 10 shows the evaluated relative closeness (Ci) and Rank of TOPSIS. The best combination of machining parameters in turning can be arranged as 19-1-10-22-20-11-2-23-21-3-13-4-25-12-14-5-16-24-7-26-17-15-6-8-27-18-9 through TOPSIS.

Results of analysis of variance for the grey relational grade are shown in Table 11 which indicates that the feed rate is the most significant machining 
OPTIMIZATION ON TURNING PARAMETERS OF 15-5PH STAINLESS STEEL USING TAGUCHI ...

Table 10.

Evaluated relative closeness $\left(C_{i}^{*}\right)$ and rank of TOPSIS

\begin{tabular}{|c|c|c|c|c|c|c|c|c|c|c|}
\hline \multirow[t]{2}{*}{$\begin{array}{l}\text { Exp. } \\
\text { No. }\end{array}$} & \multirow{2}{*}{\begin{tabular}{|c|}
$\begin{array}{c}\text { Cutting } \\
\text { force }\end{array}$ \\
$F_{z}$ \\
\end{tabular}} & \multirow{2}{*}{$\begin{array}{c}\begin{array}{c}\text { Surface } \\
\text { roughness }\end{array} \\
R_{a}\end{array}$} & \multicolumn{2}{|c|}{$\begin{array}{c}\text { Normalised } \\
\text { decision } \\
\text { matrix }\left(R_{i j}\right)\end{array}$} & \multicolumn{2}{|c|}{$\begin{array}{c}\text { Weighted } \\
\text { normalised } \\
\text { value }\left(V_{i j}\right)\end{array}$} & \multicolumn{2}{|c|}{$\begin{array}{c}\text { Separation } \\
\text { measures }\end{array}$} & \multirow{2}{*}{$\begin{array}{c}\begin{array}{c}\text { Relative } \\
\text { closeness }\end{array} \\
C_{i}^{*} \\
\end{array}$} & \multirow[t]{2}{*}{ Rank } \\
\hline & & & $F_{z}$ & $R_{a}$ & $F_{z}$ & $R_{a}$ & $S_{i}^{*}$ & $S_{i}^{\prime}$ & & \\
\hline 1 & 83.25 & 0.54 & 0.0603 & 0.0871 & 0.030 & 0.0435 & \begin{tabular}{|l|l|}
0.0194 \\
\end{tabular} & 0.1820 & 0.9033 & 2 \\
\hline 2 & 222.64 & 0.65 & 0.1613 & 0.1043 & 0.080 & 0.0521 & \begin{tabular}{|l}
0.0577 \\
\end{tabular} & \begin{tabular}{|l|l}
0.1401 \\
\end{tabular} & 0.7081 & 7 \\
\hline 3 & 302.12 & 0.51 & 0.2188 & 0.0819 & 0.109 & 0.0409 & 0.0810 & 0.1338 & 0.6228 & 10 \\
\hline 4 & 130.24 & 1.13 & 0.0943 & 0.1823 & 0.047 & 0.0911 & 0.0691 & \begin{tabular}{|l}
0.1407 \\
\end{tabular} & 0.6703 & 12 \\
\hline 5 & 251.24 & 1.19 & 0.1820 & 0.1920 & 0.091 & 0.0960 & \begin{tabular}{|l|l|}
0.0942 \\
\end{tabular} & \begin{tabular}{|l|l}
0.1017 \\
\end{tabular} & 0.5191 & 16 \\
\hline 6 & 390.75 & 1.22 & 0.2831 & 0.1968 & 0.141 & 0.0984 & 0.1339 & \begin{tabular}{|l|}
0.0681 \\
\end{tabular} & 0.3373 & 23 \\
\hline 7 & 196.5 & 1.66 & 0.1423 & 0.267 & 0.071 & 0.1336 & 0.1169 & 0.1020 & 0.4660 & 19 \\
\hline 8 & 315.5 & 1.88 & 0.2285 & 0.3031 & 0.114 & 0.1515 & 0.1527 & \begin{tabular}{|l}
0.0560 \\
\end{tabular} & 0.2684 & 24 \\
\hline 9 & 468.22 & 1.99 & 0.3392 & 0.3210 & 0.169 & 0.1605 & 0.1951 & 0 & 0 & 27 \\
\hline 10 & 104.13 & 0.53 & 0.0754 & 0.0856 & 0.037 & 0.0428 & 0.0201 & \begin{tabular}{|l|l|}
0.1768 \\
\end{tabular} & 0.8975 & 3 \\
\hline 11 & 183.47 & 0.65 & 0.1329 & 0.1048 & 0.066 & 0.0524 & 0.0460 & 0.1494 & 0.7643 & 6 \\
\hline 12 & 279.38 & 0.87 & 0.2024 & 0.1403 & 0.101 & 0.0701 & 0.0846 & 0.1133 & 0.5723 & 14 \\
\hline 13 & 127.02 & 1.13 & 0.0920 & 0.1823 & 0.046 & 0.0911 & 0.0689 & 0.1417 & 0.6728 & 11 \\
\hline 14 & 236.97 & 1.08 & 0.1716 & 0.1742 & 0.085 & 0.0871 & 0.0841 & 0.1113 & 0.5697 & 15 \\
\hline 15 & 382.82 & 1.21 & 0.2773 & 0.1952 & 0.138 & 0.0976 & 0.1310 & \begin{tabular}{|l|}
0.0701 \\
\end{tabular} & 0.3485 & 22 \\
\hline 16 & 180.76 & 1.58 & 0.1309 & 0.2554 & 0.065 & 0.1277 & 0.1094 & \begin{tabular}{|l|l|}
0.1091 \\
\end{tabular} & 0.4993 & 17 \\
\hline 17 & 251.84 & 1.64 & 0.1824 & 0.2646 & 0.091 & 0.1323 & 0.1242 & \begin{tabular}{|l}
0.0833 \\
\end{tabular} & 0.4013 & 21 \\
\hline 18 & 431.36 & 1.87 & 0.3125 & 0.3017 & 0.156 & 0.1508 & 0.1788 & \begin{tabular}{|l|l|}
0.0164 \\
\end{tabular} & 0.0844 & 26 \\
\hline 19 & 95.37 & 0.30 & 0.0690 & 0.0481 & 0.034 & 0.0240 & 0.0043 & 0.1919 & 0.9776 & 1 \\
\hline 20 & 160 & 0.59 & 0.1159 & \begin{tabular}{|l|}
0.0951 \\
\end{tabular} & 0.058 & 0.0475 & \begin{tabular}{|l}
0.0364 \\
\end{tabular} & \begin{tabular}{|l|l|}
0.1588 \\
\end{tabular} & 0.8135 & 5 \\
\hline 21 & 260.09 & 0.51 & 0.1884 & 0.0822 & 0.094 & 0.0411 & 0.0662 & 0.1412 & 0.6805 & 9 \\
\hline 22 & 105.12 & 0.73 & 0.0761 & 0.1177 & 0.038 & 0.0588 & 0.0356 & 0.1662 & 0.8232 & 4 \\
\hline 23 & 207.13 & 0.74 & 0.1500 & 0.1194 & 0.075 & 0.0597 & 0.0572 & \begin{tabular}{|l|l|}
0.1382 \\
\end{tabular} & 0.7070 & 8 \\
\hline 24 & 351.11 & 0.88 & 0.2543 & 0.1419 & 0.127 & 0.0709 & 0.1077 & \begin{tabular}{|l|l|}
0990 \\
\end{tabular} & 0.4790 & 18 \\
\hline 25 & 172.73 & 1.33 & 0.1251 & 0.2146 & 0.062 & 0.1073 & 0.0893 & 0.1195 & 0.5723 & 13 \\
\hline 26 & 263.68 & 1.41 & 0.1910 & 0.2275 & 0.095 & 0.1137 & 0.1109 & 0.0876 & 0.4412 & 20 \\
\hline 27 & 405.62 & 1.63 & 0.2938 & 0.2630 & 0.1469 & 0.1315 & 0.1586 & \begin{tabular}{|l|l|}
0.0368 \\
\end{tabular} & 0.1884 & 25 \\
\hline
\end{tabular}

parameter $(54.30 \%)$ which affects the multiple performance characteristics and it is followed by depth of cut $(36.80 \%)$ and the cutting speed $(4.87 \%)$.

Both the results of grey relational approach and TOPSIS reveals that the 19th experiment, i.e. cutting speed $220 \mathrm{~m} / \mathrm{min}$, feed rate $0.1 \mathrm{~mm} / \mathrm{rev}$ and depth of cut $0.3 \mathrm{~mm}$ is the optimal parameter for obtaining better machining performance. 
D. PALANISAMY, P. SENTHIL

Table 11

ANOVA for grey relation grade

\begin{tabular}{|c|c|c|c|c|c|c|}
\hline Source & DF & Seq SS & Adj SS & Adj MS & F & \% C \\
\hline speed & 2 & 0.0337 & 0.0337 & 0.0168 & 64.05 & 4.87 \\
\hline feed & 2 & 0.3755 & 0.3755 & 0.1877 & 713.32 & 54.3 \\
\hline doc & 2 & 0.2545 & 0.2545 & 0.1272 & 483.45 & 36.8 \\
\hline speed· feed & 4 & 0.0068 & 0.0068 & 0.001 & 6.51 & 0.99 \\
\hline feed· doc & 4 & 0.0145 & 0.0145 & 0.0036 & 13.78 & 2.09 \\
\hline speed· doc & 4 & 0.0042 & 0.0042 & 0.001 & 4.04 & 0.6 \\
\hline Error & 8 & 0.0021 & 0.0021 & 0.0002 & & \\
\hline Total & 26 & 0.6915 & & & & \\
\hline
\end{tabular}

\section{Conclusions}

Turning operations were conducted with TiAlN coated tool on 15-5 PH stainless steel and the process parameters were analysed in terms of surface roughness and cutting force by varying the cutting speed, feed rate and depth of cut. Using grey relational analysis and TOPSIS, the multi objective optimization was performed and its optimum machining conditions were determined. The following conclusions were made.

- From the statistical analysis, it is clear that depth of cut is the most influencing parameter that affects cutting force $\left(F_{z}\right)$ while feed is the most influencing factor which affects surface roughness $\left(R_{a}\right)$. GRA is used to reveal the influencing parameter affecting both $F_{z}$ and $R_{a}$ and it is concluded that feed rate is the predominant parameter that affects both $F_{z}$ and $R_{a}$.

- From GRA, the optimum machining parameters were identified as cutting speed $220 \mathrm{~m} / \mathrm{min}$, feed rate $0.1 \mathrm{~mm} / \mathrm{rev}$ and depth of cut $0.3 \mathrm{~mm}$, i.e. 19th experiment.

- From the relative closeness values of TOPSIS, the best combination of machining parameters can be arranged in the order19-1-10-22-20-11-223-21-3-13-4-25-12-14-5-16-24-7-26-17-15-6-8-27-18-9 respectively. It is identified that the machining parameter selected as alternative 19 is the first choice. From the experimental plan (Table 3) the corresponding process parameters related to alternative 19 are cutting speed of 220 $\mathrm{m} / \mathrm{min}$, feed rate of $0.1 \mathrm{~mm} / \mathrm{rev}$ and depth of cut of $0.3 \mathrm{~mm}$.

- A similarity is found between the results of TOPSIS and GRA. 


\section{References}

[1] 15-5PH Stainless Steel, UNS S15500.AK Steel. 2004. AK Steel Corporation, 2005. http://www.aksteel.com/pdf/marketsproducts/stainless/precipitation/15-5PhDataSheet.pdf.

[2] Metals Handbook. Machining, volume 16. ASM International, Materials Park, $\mathrm{OH} 44073$.

[3] J.P. Davim. Machining: fundamentals and recent advances. Springer Science \& Business Media, 2008.

[4] A. Kumar, Y. Balaji, N. E. Prasad, G. Gouda, and K. Tamilmani. Indigenous development and air worthiness certification of 15-5 $\mathrm{PH}$ precipitation hardenable stainless steel for aircraft applications. Indian Academy of Sciences. Sadhana, 38(1):3-23, 2013.

[5] A. Braghini Junior, A.E. Diniz, and F.T. Filho. Tool wear and tool life in end milling of 15-5 $\mathrm{PH}$ stainless steel under different cooling and lubrication conditions. The International Journal of Advanced Manufacturing Technology, 43(7-8):756-764, 2009.

[6] R.L. Liu and M.F. Yan. Improvement of wear and corrosion resistances of 17-4PH stainless steel by plasma nitrocarburizing. Materials \& Design, 31(5):2355-2359, 2010.

[7] M.F. Yan, R.L. Liu, and D.L. Wu. Improving the mechanical properties of 17-4PH stainless steel by low temperature plasma surface treatment. Materials \& Design, 31(4):2270-2273, 2010.

[8] Z. Wang, C. Jiang, X. Gan, Y. Chen, and V. Ji. Influence of shot peening on the fatigue life of laser hardened 17-4PH steel. International Journal of Fatigue, 33(4):549-556, 2011.

[9] Zhaoyun Chen, Guan Zhou, and Zhonghua Chen. Microstructure and hardness investigation of 17-4PH stainless steel by laser quenching. Materials Science and Engineering: A, 534:536-541, 2012.

[10] M. Abdelshehid, K. Mahmodieh, K. Mori, L. Chen, P. Stoyanov, D. Davlantes, J. Foyos, J. Ogren, R. Clark, and O.S. Es-Said. On the correlation between fracture toughness and precipitation hardening heat treatments in 15-5PH stainless steel. Engineering Failure Analysis, 14(4):626631, 2007.

[11] M. Aghaie-Khafri and A. Zargaran. High temperature tensile behavior of a PH stainless steel. Materials Science and Engineering: A, 527(18):4727-4732, 2010.

[12] B. Fnides and M.A. Yallese. Cutting forces and surface roughness in hard turning of hot work steel X38CrMoV5-1 using mixed ceramic. Mechanics, 70(2):73-78, 2016.

[13] M.Y. Noordin, V.C. Venkatesh, and S. Sharif. Dry turning of tempered martensitic stainless tool steel using coated cermet and coated carbide tools. Journal of Materials Processing Technology, 185(1):83-90, 2007.

[14] D.A. Axinte and R.C. Dewes. Surface integrity of hot work tool steel after high speed milling-experimental data and empirical models. Journal of Materials Processing Technology, 127(3):325-335, 2002.

[15] J. Prasanna, L. Karunamoorthy, M. Venkat Raman, S. Prashanth, and D. Raj Chordia. Optimization of process parameters of small hole dry drilling in Ti-6Al-4V using Taguchi and grey relational analysis. Measurement, 48:346-354, 2014.

[16] E. Kuram and B. Ozcelik. Multi-objective optimization using Taguchi based grey relational analysis for micro-milling of al 7075 material with ball nose end mill. Measurement, 46(6):18491864, 2013.

[17] C.J. Tzeng, Y.H. Lin, Y.K. Yang, and M.C. Jeng. Optimization of turning operations with multiple performance characteristics using the Taguchi method and grey relational analysis. Journal of Materials Processing Technology, 209(6):2753-2759, 2009.

[18] C. Camposeco-Negrete. Optimization of cutting parameters for minimizing energy consumption in turning of AISI 6061 T6 using Taguchi methodology and ANOVA. Journal of Cleaner Production, 53:195-203, 2013. 
[19] Y.Tansel İç. An experimental design approach using TOPSIS method for the selection of computer-integrated manufacturing technologies. Robotics and Computer-Integrated Manufacturing, 28(2):245-256, 2012.

[20] V.S. Gadakh. Parametric optimization of wire electrical discharge machining using TOPSIS method. Advances in Production Engineering \& Management, 7(3):157-164, 2012.

[21] Y.Tansel İç. A TOPSIS based design of experiment approach to assess company ranking. Applied Mathematics and Computation, 227:630-647, 2014.

[22] S. Vinodh, M. Prasanna, and N.H. Prakash. Integrated Fuzzy AHP-TOPSIS for selecting the best plastic recycling method: A case study. Applied Mathematical Modelling, 38(19):46624672, 2014.

[23] P.J. Ross. Taguchi techniques for quality engineering. McGraw-Hill, New York, 1998.

[24] D.P. Selvaraj and P. Chandramohan. Optimization of surface roughness of AISI 304 austenitic stainless steel in dry turning operation using Taguchi design method. Journal of Engineering Science and Technology, 5(3):293-301, 2010.

[25] B.M. Gopalsamy, B. Mondal, and S. Ghosh. Taguchi method and ANOVA: An approach for process parameters optimization of hard machining while machining hardened steel. Journal of Scientific \& Industrial Research, 68(8):686-695, 2009.

\section{Optymalizacja parametrów toczenia stali nierdzewnej 15-5PH z wykorzystaniem „szarej” analizy relacyjnej opartej na metodzie Taguchi i metody TOPSIS}

Streszczenie

Optymalizację parametrów procesu toczenia stali nierdzewnej typu 15-5 utwardzanej wydzieleniowo (PH) badano stosując ,szarą” analizę relacyjną (GRA) opartą na metodzie Taguchi i metodę rozwiązywania problemów decyzyjnych TOPSIS. Układ planowanych eksperymentów przedstawiono w formie tablicy ortogonalnej $L_{27}$. Miarami jakości procesu były siła skrawania $\left(F_{z}\right)$ i chropowatość powierzchni $\left(R_{a}\right)$. Miary te zostały zoptymalizowane w celu poprawy skrawalności. Przeprowadzono porównanie pomiędzy różnymi wielokryterialnymi metodami decyzyjnymi. Zastosowano ,,szarą" analizę relacyjną (GRA) i metodę TOPSIS by potwierdzić i udowodnić podobieństwo wyników. Zastosowano analizę wariancji (ANOVA) by wyznaczyć wpływy parametrów procesu toczenia. Wyniki końcowe badań eksperymentalnych potwierdzają, że jakość skrawania może być efektywnie podwyższona przy zastosowaniu wspomnianych metod. 